\title{
Community Resilience: An Integrative Literature Review Study
}

\author{
Ana Tercila Campos Oliveira*,1 \\ Orcid.org/0000-0001-7254-3969 \\ Normanda Araujo de Morais ${ }^{1}$
}

Orcid.org/0000-0003-3156-4688

${ }^{1}$ Universidade de Fortaleza, Fortaleza, CE, Brasil

\begin{abstract}
A national and international integrative literature review on the topic of community resilience (CR) was performed, focusing on the period from 2009 to 2015. Specifically, we sought to describe the concepts of CR developed in articles, the main adversities cited and the factors related to CR. The search was conducted using the SciELO database and Portal de Periódicos Capes, and from the inclusion and exclusion criteria, 34 articles were identified. Most articles were found in the English language, especially from North America, published in 2013, and used a qualitative method, based on interviews. With regard to the concept of CR, it was found that this can be seen as an attribute (ability and skill) and a process. The main adversities that were studied were disasters (hurricanes, earthquakes, floods, terrorist attacks and armed conflicts). There are three factors related to CR: social capital, cultural ties and the infrastructure that supports the development of community members. Finally, the great potential of theoretical and practical contribution of this concept to the overcoming of adversities common to the Brazilian community context is underlined.
\end{abstract}

Keywords: Community resilience, community, social capital.

\section{Resiliência Comunitária: Um estudo de Revisão Integrativa da Literatura}

\section{Resumo}

Realizou-se uma revisão integrativa da literatura (nacional e internacional) sobre o tema da resiliência comunitária (RC), no período de 2009 a 2015. Especificamente, buscou-se descrever os conceitos de $\mathrm{RC}$ trabalhados nos artigos, as principais adversidades citadas e os fatores relacionados à RC. A busca foi feita no SciELO e no Portal de Periódicos Capes e, a partir dos critérios de inclusão e exclusão, identificaram-se 34 artigos. Predominaram os artigos na língua inglesa, sobretudo norte-americanos, publicados em 2013, de método qualitativo e baseado em entrevistas. Sobre o conceito de RC, verificou-

* Mailing address: Universidade de Fortaleza, Programa de Pós-Graduação em Psicologia, Avenida Washington Soares, 1321, Edson Queiroz, Fortaleza, CE, Brazil 60.811-905. E-mail: tercilacampos@hotmail.com Agradecimento: As autoras agradecem à Fundação Cearense de Apoio ao Desenvolvimento Científico e Tecnológico (FUNCAP) e ao Conselho Nacional de Desenvolvimento Científico e Tecnológico (CNPQ), respectivamente, pelas Bolsas de Mestrado e de Produtividade II em Pesquisa. 
se que esta pode ser vista como um atributo (capacidade, habilidade) e enquanto processo. As principais adversidades estudadas são os desastres (furacões, terremotos, enchentes, ataques terroristas e conflitos armados). E três fatores estão relacionados à RC: capital social, laços culturais e a infraestrutura que apoia o desenvolvimento dos membros da comunidade. Por fim, sublinha-se o grande potencial de contribuição teórica e prática desse conceito para a superação de adversidades comuns ao contexto comunitário brasileiro.

Palavras-chave: Resiliência comunitária, comunidade, capital social.

\section{Resiliencia Comunitaria: Un estudio de Revisión Integradora de la Literatura}

\section{Resumen}

Se llevó a cabo una revisión integradora de la literatura (nacional y internacional) sobre el tema de la resiliencia comunitaria (RC), en el periodo desde 2009 hasta 2015. Específicamente, buscamos describir los conceptos de RC utilizados en los artículos, las principales adversidades y factores relacionados con la RC. La busqueda se realizó en el SciELO y en el Portal de Periódicos Capes y, a partir de los criterios de inclusión y exclusión, se identificaron 34 artículos. Predominaron los artículos en inglés, especialmente los estadounidenses, publicados en 2013, y el método cualitativo basado en entrevistas. Sobre el concepto de RC, se concluyó que se puede verlo como un atributo (capacidad, habilidad) y también como un proceso. Las principales dificultades estudiadas fueron los desastres (huracanes, terremotos, inundaciones, ataques terroristas y conflictos armados). $\mathrm{Y}$ tres factores fueran relacionados con la RC: el capital social, los lazos culturales y la infraestructura que apoya el desarrollo de los miembros de la comunidad. Por último, se pone en evidencia el gran potencial y contribución teórico y práctico de este concepto para la superación de las adversidades comunes al contexto comunitario brasileño.

Palabras claves: Resiliencia comunitaria, comunidad, capital social.

From the beginning of the history of humanity, communities, societies and civilizations have needed to use adaptive capacities to survive major social and environmental changes. In contemporary times, the challenges have multiplied. Globalization, climate change and unbridled economic growth can cause stressful situations for individuals and communities, these include natural, technological or human disasters, wars, epidemics and social inequality. The term resilience has been used by many experts to explain the adaptive and health related responses that individuals and groups present when confronted with challenges, generating a growing body of research on the subject (Smith, Moore, Anderson, \& Siderelis, 2012; Wilson, 2012).

Psychological resilience was initially investigated at the individual level in an attempt to understand how some children were able to develop healthily despite exposure to serious adverse conditions such as parental mental disorder and extreme poverty. At first, resilience was understood as an innate or acquired attribute, and children who presented such a phenomenon were considered invulnerable, that is, able to withstand adversities without suffering any impact (Rutter, 1993). More recent research reveals, however, thatresiliencecannotbeviewed as static, but rather as a dynamic and subjective process, in which individual characteristics are related to the risk and protection factors found in the contexts in which the subject is inserted. Thus, more recently, resilience has been described by many researchers as a set of social and psychic processes that enable someone to cope in adverse situations, resulting in adaptation and positive transformation (Morais \& Koller, 2011; Poletto \& Koller, 2008). 
Along with the studies of Psychology and Psychiatry on resilience, the concept was researched in other fields of knowledge, particularly Ecology. In 1973, Holling published the "Resilience and Stability of Ecological Systems" thesis on ecological resilience, in which the term was used to describe an ecosystem's ability to absorb change and adapt to it while maintaining its existing state of functioning (Boon, Cottrell, King, Stevenson, \& Millar, 2012). The ecosystem view of resilience perceives the individual embedded in a web of complex relationships, so that the individual, the family, and the larger environment are interconnected and factors from each sphere contribute to the coping process (Kirmayer, Sehdev, Whitley, Dandeneau, \& Isaac, 2009). Since the emergence of this view, the concept of resilience has been applied not only to understand adaptive capabilities presented by individuals but also by human communities and larger societies (Norris, Stevens, Pfefferbaum, Wyche, \& Pfefferbaum, 2008).

Although community resilience is not a construct from Community Psychology, it is possible to perceive similarities between its proposals and concerns. Community Psychology is the area of Psychology that seeks to understand the daily and objective life of people in a given socio-historical reality and how this way of life influences and is influenced by its residents. One of the main objectives of Community Psychology is to contribute to community development, which occurs through the awareness and empowerment of its residents, enabling the development of their own resources and potentialities. This process facilitates the participative and shared organization and actions of the residents towards the confrontation and resolution of their problems, reaching autonomy and overcoming of social inequalities (Góis, 2008; Montero, 1984; Quintal, 2016). Since community resilience consists of group coping processes and adaptation to collective challenges, its study has the potential to bring contributions to Community Psychology, especially if applied to interventions in situations of chronic adversity, such as drought, social inequality, urban violence, among many others found in the Brazilian and Latin American context.

The investigation of the concept of community resilience in the literature shows the existence of two theoretical traditions, one Latin American and one North American. The Latin American is represented by the Argentine researcher Élbio Néstor Suárez Ojeda. His concept of community resilience has become more accessible to Brazilian researchers, since some books containing chapters written by him have been published in Portuguese (Ojeda, 2005; Ojeda, La Jara, \& Márquez, 2007). The articles of the North American tradition, on the other hand, are comparatively less cited in the national literature, a fact that can also be related to the restricted accessibility to the English language texts, as well as the fact that it is a subject of very recent interest in the Brazilian context. In addition, it is worth noting that, although it is possible to perceive similarities between what is proposed by the theoretical currents of community resilience (Latin American and North American), the studies of one do not refer to another.

Studies and projects to promote resilience in Latin America tend to focus on populations defined by poverty and discrimination, with interventions focused on the social meaning, since the continent is prone to different disasters, stemming from the geographic and social conditions (Ojeda, 2005; Ojeda et al., 2007). In this sense, Ojeda et al. (2007) states that the Latin American contribution to the concept of resilience is greater in respect to the collective approach because it is more rooted in social epidemiology than in the classically studied health-disease processes.

Ojeda (2005) acknowledges the damage suffered by the community when there is a disaster or catastrophe, but emphasizes that this painful situation can also mean mobilizing the resources and solidarity creating capabilities of the population to promote physical and social transformations in the community. It is as if the communities had a "protective shield," which emerges from their own living conditions and values and allows for the metabolization of a negative event 
and the possibility of building from it. Through the evaluation of resilience in several communities that suffered disasters, the author observed the conditions that appear more frequently in those that overcome the danger with more rapidity and success, and identified the pillars of community resilience, namely: solidarity, state honesty, cultural identity, collective self-esteem and social humor (Ojeda et al., 2007).

Solidarity is perceived as adherence to the group cause, with the purpose of overcoming adversities and gaining benefits common to all. State honesty is seen as the trust of community members that their governors manage the "public affairs' honestly and transparently. Cultural identity refers to the recognition and appreciation of what is proper to a particular culture, including customs, values, dances, songs and idiomatic expressions, which gives members a sense of belonging. Social humor is understood as the ability of some people to find comedy in their own tragedy, a strategy that contributes to the acceptance of common misfortune, favoring a distancing from the problem and enabling its resolution. Collective self-esteem refers to the individual's attitude and sense of pride in the place where they live, including a love for their land, awareness of its natural beauty, and identification with certain significant human customs and productions.

The scientific research about community resilience outside the Latin American context tends to follow the North American concept, whose conceptual framework is the publication of an article produced by Fran Norris and collaborators in 2008. The paper presents a theory of resilience that encompasses the contemporary understanding of stress, adaptation, well-being and dynamic resources. According to Norris et al. (2008), community resilience is the process that links a network of adaptive capabilities (resources with dynamic attributes) of the community to a positive trajectory of functionality and adaptation after a disturbance or adversity. The result of the resilience process is community adaptation, manifested by the well-being of the population, which can be defined as high and non-disparate levels of mental and behavioral health, proper functioning of the various social roles and quality of life (how people generally feel about their lives as a whole). This definition links the concept of resilience to traditional concerns in the field of public health and mental health.

The dynamic attributes of the resources found in a community are: robustness, when the resource is strong and presents low probability of deterioration; redundancy, variety and abundance of resources, which allows the elements to be replaced in the event of their degradation; and speed, how fast a resource can be accessed and used. According to the resistance and resilience model proposed by Norris et al. (2008), the community can follow three paths in the face of exposure to a stressor event: resistance, situational transient dysfunction followed by a process of resilience or permanent dysfunction. The most likely result that a community presents in the face of stressor events is situational transient dysfunction, characterized by a period of distress and temporary suffering, which may be followed by processes of community resilience or vulnerability. Resilience occurs when the community's dynamic resources are able to neutralize the effects of stressors, allowing adaptation to the altered environment and return to functioning after the period of transient dysfunction. Thus, community resilience emerges from interconnected adaptive sets of capabilities that capture the combination of the resources themselves with their dynamic attributes - robustness, redundancy, and speed. The primary adaptive capacities are: Economic Development, Social Capital, Information and Communication, and Community Competence (Norris et al., 2008).

The economic development of a community fosters its resilience insofar as it offers volume and diversity in economic resources as well as equality in their distribution. Poor communities are more likely to have dysfunctional psychological, social, and physical reactions due to the vulnerability they suffered before the disaster. Social capital refers to the individual's rela- 
tionships with the social networks in which he or she is part of, which provide social support and connection with the community. Information and communication is important in regard to the risks that people suffer, the directions to be taken, the coordination of volunteers and the services available, which help to raise survival levels in case of emergency. Community competence refers to decision-making capabilities, meaningful and intentional collective action, empowerment, constructive engagement ability in group processes, mutual trust and willingness to work for the common good of the community (Norris et al., 2008).

In Brazil, scientific production on the subject of community resilience is still considered incipient. The adversities experienced by the Brazilian population and their possibilities of confrontation have been widely discussed by Community Psychology, but only recently has the focus of resilience been used to analyze such phenomena. Some studies that contribute to the development of the state of the art on community resilience in the Brazilian context were published in a book published in 2015 on resilience (Coimbra \& Morais, 2015). In the first chapter that addresses the theme, there is the report on the fire at the Kiss nightclub in Santa Maria / RS, and the post-disaster intervention that was carried out and the observed community resilience processes (Zappe, Yunes, \& Dell'aglio, 2015). The second chapter, in turn, deals with the resilience processes experienced by residents of the bushlands of Ceará, facing the difficulties caused by the natural phenomenon of drought (Morais, Figueiredo, Rodrigues, \& Santos, 2015).

The study of community resilience makes it possible to identify factors that contribute to collective processes of coping with adversity. It is a phenomenon that can be encouraged, when considering the responsibility of the community itself, given its complexity and potential for transformation, as well as for the external agents (professionals, government and private sector) responsible for providing physical and economic resources (White, Edwards, Farrar, \& Plodinec, 2014). Thus, the need becomes clear to increase the knowledge about the factors that are consid- ered important in the promotion of community resilience in Brazil and in the world so that one can think of strategies of effective intervention and promotion of resilience for the communities that experience some kind of adversity.

This study aimed to carry out an integrative review of the literature (national and international) on the theme of community resilience, from 2009 to June 2015, in order to identify the state of the art on the theme, specifically in three aspects: the concept of community resilience, the main adversities studied and the factors that favor community resilience. It is expected that the result of this integrative review will help shed important light on the subject and motivate the development of further empirical studies that consider the adversities and processes of community resilience specific to the national scenario, such as floods, drought, fires and social inequality.

\section{Method}

It is an Integrative Review of Literature, whose objective is to gather, critically evaluate and synthesize, in a systematic way, the results of multiple studies on a given topic, contributing to deepening the knowledge about the investigated question (Mendes, Silveira, \& Galvão, 2008). In order to guide and systematize the implementation of the literature review, eight steps were followed: (1) identification of the theme and delimitation of the guiding question; (2) choice of databases; (3) definition of the descriptors for the search; (4) search and storage of results; (5) selection of articles by summary, according to inclusion and exclusion criteria; (6) obtaining the data of the selected articles; (7) evaluation of the articles; and (8) synthesis and interpretation of data.

\section{Procedures}

In order to carry out the search, the Capes Journal Portal, which offers access to articles indexed in several databases, and the SciELO database were selected. In Portuguese the descriptor "resiliência comunitária" was used and in English the descriptor "community 
resilience" was used. The search in the bases established the period between 2009 and June 2015 , with the intention of mapping the most recent production (last seven years), as well as being written after the defining article published by Norris et al. (2008).

The database search was conducted using the period May and June 2015 and used the following inclusion criteria: indexed articles; published in peer-reviewed journals; written in Portuguese, English and Spanish; theoretical and empirical articles; articles that have the term "community resilience" in the title and / or keywords; available in its full version; published between the years of 2009 and June 2015; and performed with human beings. It was decided to only use the descriptor "community resilience" and just this, as well as to include only articles that presented the term in the title or keywords, in order to better delimit the search and emphasize those studies that investigated specifically community resilience, namely the process of overcoming adversities experienced at the community level.

Subsequently, abstracts were analyzed, considering the following exclusion criteria: duplicate articles; "Gray literature" - book chapters, news, technical papers, comments, editorials, dissertations and theses; published outside the period between 2009 and June 2015; and studies that did not have objectives related to indicators of community resilience. After the selection of the abstracts, the complete articles were retrieved and submitted to the evaluation of three independent judges, who were all graduate students and members of the research group of which the authors of this article are also part. The judges clarified the exclusions and the divergences resolved by consensus. Finally, the selected studies were read in full and the extraction of data was stored in Excel spreadsheets.

\section{Data Analysis}

In order to obtain the synthesis and interpretation of the results, two types of analysis were performed. The first was quantitative (through the calculation of frequencies), where the aim was to outline the scientific production, especially in relation to the following indicators: year of publication, language, nationality of the institutions of the first authors, journals, nature of the article (empirical or theoretical), approach (quantitative, qualitative or multi-method) and data collection instruments. In the second qualitative analysis, the contents were organized and synthesized through Bardin's Content Analysis (1977) and the following thematic categories emerged: definitions of community resilience, contexts of adversity reported in articles, and factors favoring community resilience.

\section{Results and Discussion}

The initial search in the databases was performed with filters delimiting the period of publication (2009-2015) and including only publications in peer reviewed journals. A total of 417 studies were identified. Before reading the abstracts, the other inclusion and exclusion criteria were applied, with the following data: duplicate articles $(n=122)$; research with nonhumans $(n=45)$; publications that were not articles $(n=24)$; articles that did not have the term "community resilience" in the title and / or keywords $(n=135)$; and studies that did not have an objective related to community resilience indicators $(n=27)$. After this selection, there were 64 studies, from which it was possible to recover the complete text of 61 , which were read in full by the researcher and evaluated by the judges. Before the evaluation, 24 articles were excluded, since they did not have in their content contributions that would help answer the original questions of the research, leaving, therefore, 37 articles that composed the body of analysis of the study. The highest number of articles was obtained from the PsycInfo database $(n=8)$, followed by John Wiley \& Sons, Inc $(n=7)$, Science Direct $(n=5)$, Pubmed and SciELO, both with 4 articles, Sage Publications and Springer Science \& Business Media BV with 2 articles, and, finally, PsycArticles, ERIC, Proquest, National Library of Medicine and Scopus with 1 article each. Figure 1 summarizes the methodological path of article selection. 
417 Records identified through database search (published between 2009 and June 2015 in peer-reviewed journals)

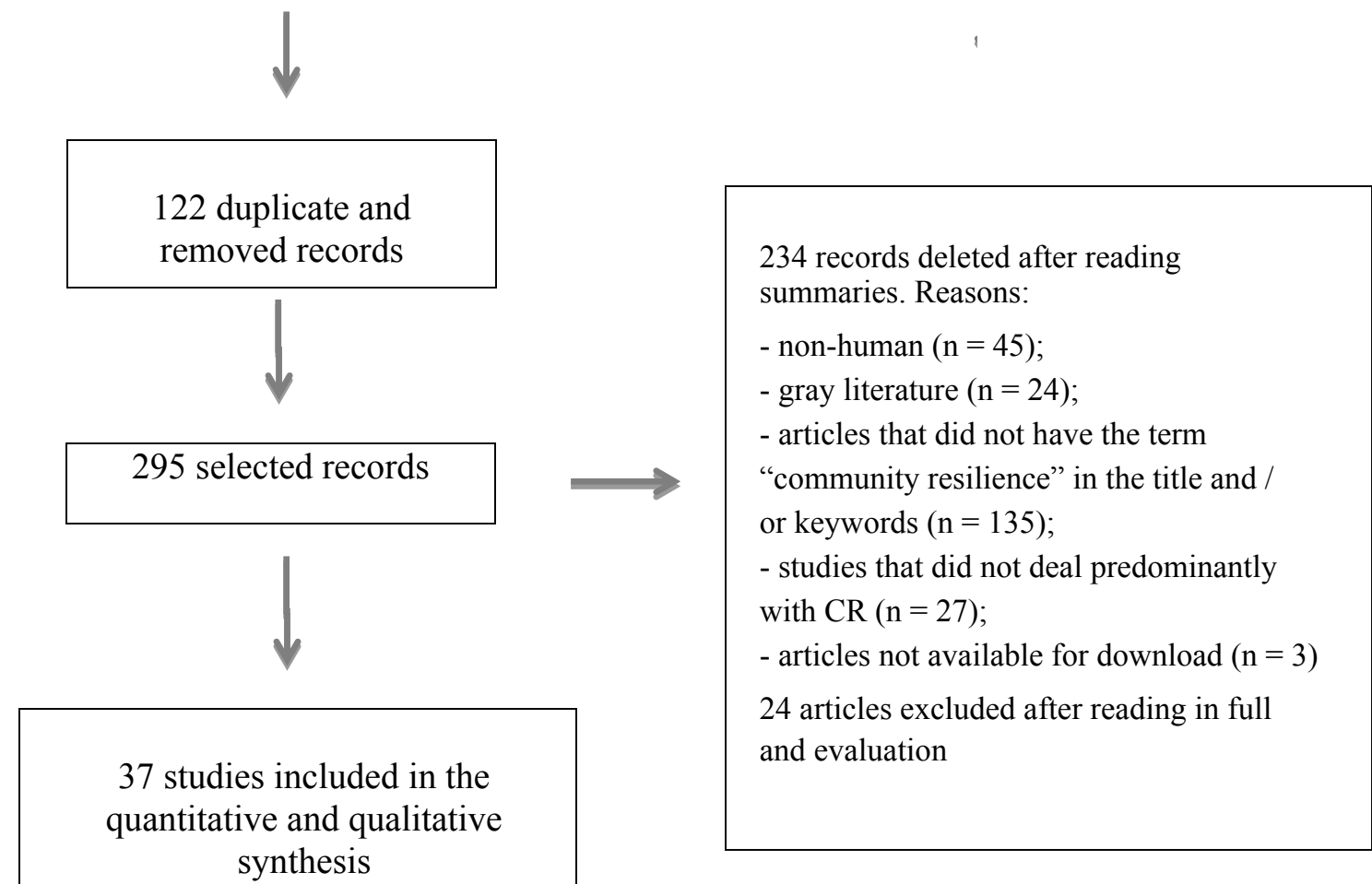

Figure 1. Diagram of the selection process of articles according to inclusion and exclusion criteria

\section{Quantitative Characterization of Scientific Productions}

Among the articles analyzed, most of the studies were written in the English language ( $n$ $=33)$, with three studies in Spanish $(n=3)$ and one in Portuguese $(n=1)$. As for the origin of the institutions of the authors, the majority came from the United States $(n=17)$, followed by the United Kingdom $(n=7)$ and Australia $(n=$ $3)$. Of the 37 articles found, only 4 are of Latin American origin, which can be attributed to the lack of reach of the articles from that region to the journals indexed in the selected databases. One hypothesis is that the scarcity of Brazilian and Latin American studies is an indicator that in these countries the conceptual contribution to the study of organizational processes and of the potentialities and challenges faced by the communities is regarded as a different field, such as the Psychology of Liberation, widely disseminated and worked on in the Latin American Psychology Community.

It was observed that the number of publications on community resilience has been increasing over the years, reaching a higher number in $2013(n=11)$. In regard to methodological issues, empirical articles predominated $(n=23)$. Among these studies, the qualitative approach was the most used $(n=13)$. There is great diversity in empirical data collection strategies to access community resilience, with many of the studies making use of more than one instrument. The interview was the most frequently used instrument in the selected studies $(n=13)$. Access to public data for research purposes, such as demographic data, historical archives, published online content, and data from previous surveys was also widely used $(n=11)$. 
Table 1

Quantitative Characterization of the Recovered Studies $(n=37)$

\begin{tabular}{|c|c|}
\hline Quantitive Categories & Sample \\
\hline Language & $\begin{array}{l}\text { English }(n=33) \\
\text { Spanish }(n=3) \\
\text { Portuguese }(n=1)\end{array}$ \\
\hline Country of origin of main author & $\begin{array}{l}\text { USA }(n=17) \\
\text { United Kingdom }(n=7) \\
\text { Australia }(n=3) \\
\text { Chile }(n=2) \\
\text { Brazil, Canada, Spain, Israel, Lebanon, Mexico, } \\
\text { Norway and Sri Lanka }(n=1)\end{array}$ \\
\hline Publication year & $\begin{array}{l}2009(n=1) \\
2010(n=3) \\
2011(n=4) \\
2012(n=7) \\
2013(n=11) \\
2014(n=6) \\
\text { June } 2015(n=5)\end{array}$ \\
\hline Type of study & $\begin{array}{l}\text { Empirical }(n=23) \\
\text { Theoretical }(n=14)\end{array}$ \\
\hline Method & $\begin{array}{l}\text { Qualitative }(n=13) \\
\text { Multi-method }(n=5) \\
\text { Quantitative }(n=5)\end{array}$ \\
\hline Instrument & $\begin{array}{l}\text { Interview }(n=13) \\
\text { Public Data }(n=11) \\
\text { Questionnaires / scales / indices }(n=7) \\
\text { Field observations }(n=6) \\
\text { Group strategies }(n=4)\end{array}$ \\
\hline
\end{tabular}

\section{Qualitative Characterization of Scientific Productions}

The concept of community resilience. The analysis of the articles showed that there is no consensus regarding the concept of community resilience. There are several definitions to be found, many articles describe more than one definition when making an introductory review, in the case of empirical studies, or a broader literature review, in the case of theoretical studies. The theoretical model most cited in the articles was the one proposed by Norris et al. (2008), a result of the vast literature review published by these authors, in which community resilience is seen as a process emerging from interrelated sets of adaptive capacities. Two (Azkarraga, Sloan, Belloy, \& Loyola, 2012; Juliano \& Yunes, 2014) of the selected articles used as a reference the conceptual framework proposed by Ojeda (2005) and Ojeda et al. (2007), which describes community resilience as the processes and collective forces that allow the metabolization of the negative event and the mobilization of solidarity creating capabilities towards the reconstruction.

Faced with the devastating effects of catastrophes in recent years, such as Hurricane Katrina in 2005 and the terrorist attacks of September 11, 2001, both in the United States, community resilience has become a matter of interest for many countries, integrating national 
policies of safety and public health in some of them, including the United States (Plow et al., 2013) and Australia (Boon et al., 2012). From this perspective, several studies have addressed community resilience when applied to effective organizational behavior in disaster / emergency management (eg Harte, Childs, \& Hastings, 2009; White et al., 2014). These studies associate the concept of community resilience to the stages used in emergency management: response, recovery and preparation. The answer lies in the maintenance of emergency services to deal with the immediate effects of the catastrophic event. Recovery is the time when the public and private sectors work together to achieve a return to the former way of life and provide security to the affected area. This preparation implies the development of actions that help to minimize the destructive effects of these events if they happen again, that is, actions that allow future community resilience (Rob, 2012).

In some studies, the concept of community resilience is associated with that of inherent resilience, which consists of practices filed in the collective memory used by the community to deal with ruptures (Colten, Hay, \& Giancarlo, 2012). The studies from this perspective describe community resilience as the ability of the human system to absorb the impact and reorganize itself, maintaining the same function, structure and identity as it undergoes serious changes (González-Muzzio, 2013; Wilson, 2013b). In order to do so, the community needs both the inherent conditions of the system to face the event and the subsequent adaptive processes that facilitate the system's ability to reorganize, change and learn in response to the event (González-Muzzio, 2013). Therefore, the community is competent in the face of adversities, but it needs adequate support and encouragement to gain access to the collective forces that will transcend the loss (Agani, Landau, \& Agani, 2010).

Community resilience has also been understood in terms of resources or capital (social, physical, economic and human) that the community possesses and that can be accessed at a time of crisis. According to Ungar (2011), com- munity resilience consists of the interdependent relationship between social capital, physical infrastructure and culturally embedded standards that give the community the potential to recover from dramatic change, sustain its adaptive capability, and support a new growth that integrates the lessons learned from the crisis. Thus, recovery, sustainability, and growth are possible, but community forces need to be nurtured prior to the stressor event, significant resources need to be available to the community from the government, and the community is able to use them for the common benefit (Ungar, 2011)

According to the analysis of the publications, community resilience is therefore seen as an attribute (capacity, ability) and as a process. The definitions that use the term capacity in general are those related to emergency management and the possibility for a community to provide the resources needed to cope with adversity coupled with the ability of individuals to access them. On the other hand, the term ability is used more from an ecological perspective, in which the collective action allows for the absorbance of the disturbance, to reorganize and to maintain essentially the same functions, while undergoing change. Finally, the definition of community resilience as a process is related to the community's positive adaptation to a disaster or crisis situation. In this case, the outcome or endpoint would be adaptation (indicated by community welfare), while resilience would be the process that led the community to that outcome, including the interdependent relationship between social, cultural and economic resources, which provides the potential for dealing with adversity in the most positive way possible.

Adverse contexts. Several adverse contexts experienced by communities are described in the selected articles. Many of the theoretical studies deal with disasters in general, both natural (hurricanes, earthquakes, floods) and man-made disasters (terrorist attacks, armed conflict) as community stressors (e.g., Ungar, 2011). Disasters are extreme events, often sudden and unexpected, and can be experienced individually and collectively. They cause injury, death, destruction of physical and economic 
resources, cause chaos, interrupt routines, and seriously threaten the functioning of communities (Pfefferbaum \& Pfefferbaum, 2013). Some of these studies problematize the increase of the population vulnerable to these disasters, emphasizing the need to think about ways of reducing this vulnerability before the disaster occurs (González-Muzzio, 2013; Harte et al., 2009).

Several studies focus on natural disasters in the context of climate change, discussing current global trends such as increasing atmospheric temperatures and rising sea levels, which have as a consequence a greater likelihood of natural disasters. They are interested, therefore, in the complex relationship between the impact of climate change and the social responses that communities present, more specifically the ability to adapt successfully to these changes (E.g., Gómez-Baggethun, Reyes-García, Olsson, Montes, 2012; Smith et al., 2012).

In addition, the threat of loss of community resilience due to rapid worldwide globalization that has the consequence of economic, social and environmental vulnerability is discussed. The insertion of most communities into the global capitalist system endangers the resilience processes for some of them, because it is not always possible to find a balance between the community and its interactions at a global level. It is risky for a community to be either isolated, which can lead to a complete dependence on its local resources, or to live an exaggerated globalized existence, which can result in loss of autonomy and identity (Wilson, 2012, 2013a). From this perspective, two articles address community resilience in the context of indigenous communities, one in Alaska, the USA, and the other in Northeast Norway, both of which are facing difficulties with their youth who are growing up in a very different context from their parents and grandparents due to rapid changes (Nystad, Spein, \& Ingstad, 2014; Wexler, Joule, Garoutte, Mazziotti, \& Hopper, 2013).

The contexts of poverty and resource deprivation are discussed in two articles, both published in health journals. They discuss the relationship between deprived neighborhoods, health and community resilience (Allmark, Bhanbhro, \& Chrisp, 2014; Poortinga, 2012). According to these studies, the idea that community resilience can contribute to public health in relation to long-term threats, such as poverty, is part of the development of more recent studies on the subject. Poortinga (2012) argues that a resource deprived neighborhood is one of the most important risk factors for public health and well-being, as it limits access to education and employment opportunities, increases the stressful experience and can affect self-esteem and social support.

In this way, it is perceived that the majority of studies discuss the adversities related to disasters and emergencies. Less emphasis is placed on other issues such as the challenges posed by globalization and the vulnerability caused by poverty and deprivation of resources. Although only a few articles focus on such aspects, they may point to the beginning of community resilience studies in other fields of application of the concept that have not yet been explored.

Factors favoring community resilience. Social aspects found in the community appeared more frequently in the results of the studies as those factors indicate community resilience or contribute to its development. Social capital was widely discussed in the literature and there is a consensus on the important role it plays in community resilience processes. Government institutions in the United States and the United Kingdom have made a large financial investment in research and public policy focusing on physical infrastructure in the emergency management process (Aldrich \& Meyer, 2015). However, the authors who discuss social capital agree that the efforts undertaken in disaster preparation should be more focused on social infrastructure, since this is what drives community resilience (Aldrich \& Meyer, 2015; Poortinga, 2012; Rob, 2012).

Social Capital is formed by social support networks that the individual can access, be they informal networks (friends, neighbors and family) or formal structures of social support, such as social services and NGOs (Aldrich \& Meyer, 2015; Ungar, 2011). This construct is reflected 
through social trust, reciprocity and civil participation and has been related to high levels of subjective health, better mental health and a reduction in the adverse effects of living in disadvantaged neighborhoods (Poortinga, 2012).

Social Capital has been separated into three main types: bonding, bridging and linking. Each varies according to the strength of the relationship, the composition of the network and the different outcomes for individuals and communities. Bonding refers to connections between emotionally close individuals, such as friends, neighbors, and family members. The strong connection provides individuals with social cohesion, support and personal assistance when they need it, especially in crisis situations. Bridging describes the more distant social relations, between acquaintances or loosely connected individuals, but belonging to the same group, including race, social class or organizations (religious groups, parents' and teachers associations, and civil and political institutions). Such a link can contribute to the advancement of a particular group in society, through solidarity, respect and understanding among heterogeneous individuals. The third type of social capital, linking, connects citizens to their governors. This type of network incorporates norms of respect and relationships of trust with authorities, whether formal or institutionalized in society, that allow for the mobilization of political resources (Aldrich \& Meyer, 2015; Poortinga, 2012).

Some aspects of social capital are discussed in the articles, even if they do not refer to this term. The support found in family relationships, which corresponds to a part of social capital bonding, is considered of great importance for community resilience by some authors (e.g., Agani et al., 2010; Colten et al., 2012; Nystad et al., 2014). According to Agani et al. (2010), connectivity with the family and culture of origin is related to a reduction in risk behavior, social violence and post-traumatic stress. Promoting the strengthening of family ties and improving the access of the individual to the extended family, therefore, can be protective in situa- tions of stress. In addition, the interconnectivity with other members of the community and in turn their interconnectivity to the environment were pointed out as promoters of resilience and well-being (Nystad et al., 2014). Given that social capital can be generated or degraded (worn out), efforts should be made to strengthen social cohesion and deepen trust in communities by building bridges between groups within the community and with those in authority (Aldrich \& Meyer, 2015).

Cultural ties involving a particular group have been of great importance for community resilience. A study on the 2006 Lebanon War concluded that the sense of a collective identity and previous experience with wars favored building community resilience over time (Nuwayhid, Zurayk, Yamout, \& Cortas, 2011). Thus, local customs, inherent resilience, ethnic pride, traditional practices and rituals, beliefs and norms seem to contribute to the processes of community resilience (Gomez-Baggethun et al., 2012; Nystad et al. 2014; Wilson, 2013b).

Although not receiving much attention in the studies selected in this review, the physical infrastructure of a community, in terms of access to public transportation, leisure spaces, health, education and good quality social support, are also considered factors that promote resilience. According to Ungar (2011), when the people who most need this type of support have access to it, some risks are minimized. Thus, quality public transport can make it easier for young people on the outskirts of a city to access employment opportunities and health services; leisure spaces can ease the approximation between members of the community; and access to education expands the possibilities for the development of individuals and, consequently, of the community.

It is possible to perceive similarities between the factors found in the articles analyzed in this review, mostly considering the model of Norris et al. (2008) of community resilience, and the pillars of community resilience proposed by Ojeda (2005). Social capital encompasses the pillars of solidarity (collective actions that seek the common good of the community) and state 
honesty (relationship of trust between residents and governors). On the other hand, cultural identity, social humor and collective self-esteem relate to the relationship of members with their place of origin, forming social bonds. The attempt to integrate the results of this review with the Latin American contribution to the concept of resilience is summarized in Table 2 .

Table 2

Factors that Favor Community Resilience from the Integration of the North American and Latin American Model

\begin{tabular}{|c|c|c|}
\hline Factors & Definition & Reference Examples \\
\hline $\begin{array}{l}\text { Social } \\
\text { Capital }\end{array}$ & $\begin{array}{l}\text { Informal social support - bonds of solidarity between family, } \\
\text { neighbors and friends; } \\
\text { Formal social support - social facilities and NGOs; } \\
\text { Social groups - race, social class, associations; } \\
\text { Community organization - leadership, social cohesion, } \\
\text { community participation; } \\
\text { Relationship of trust among residents } \\
\text { and their governors }\end{array}$ & $\begin{array}{l}\text { (Agani et al., 2010; Allmark et al., } \\
\text { 2014; González-Muzzio, 2013; } \\
\text { Juliano \& Yunes, 2014; Poortinga, } \\
\text { 2012; Wyche et al., 2011) }\end{array}$ \\
\hline $\begin{array}{l}\text { Cultural } \\
\text { Ties }\end{array}$ & $\begin{array}{c}\text { Cultural identity - shared customs and beliefs; } \\
\text { Accumulated knowledge of past experiences; } \\
\text { Collective self-esteem - love and pride for place of origin; } \\
\text { Social Humor }\end{array}$ & $\begin{array}{c}\text { (Colten et al., 2012; Gómez- } \\
\text { Baggethun et al., 2012; González } \\
\text { \& Gaudino, 2013; Juliano \& Yunes, } \\
\text { 2014; Nystad et al., 2014; G. A. } \\
\text { Wilson, 2013b) }\end{array}$ \\
\hline Infrastructure & $\begin{array}{c}\text { Health; Education; Security; } \\
\text { Public transportation; } \\
\text { Leisure spaces }\end{array}$ & $\begin{array}{c}\text { (González \& Gaudino, 2013; } \\
\text { Ungar, 2011) }\end{array}$ \\
\hline
\end{tabular}

\section{Final Considerations}

This article aimed to carry out an integrative review of the literature (national and international) on the theme of community resilience, from 2009 to June 2015, in order to identify the state of the art on the subject, specifically in regard to the concept, the main adversities studied and factors that favor community resilience.

According to what was observed in the quantitative analysis, the publications on Community Resilience grew significantly only in the year of 2013, which shows how recent the discussion on this subject is. Despite being new, the theme presents great potential in contributing to ideas about the overcoming of adversities at the community level. Although it was possible to access the Latin American model of community resilience through books, only four articles originating from that continent were found in this search, which confirms the need for publications of Latin origin about this theme in journals with greater impact and visibility. In addition, it is understood that the low number of publications identified, especially in Latin American studies, may be related to the exclusive use of the descriptor "community resilience" in the title or keywords, also the limitation of including Latin American databases in the search, as well as restricting the search to articles, rather than books and book chapters. Of course, the inclusion of other descriptors (e.g. adaptation, community welfare, etc.) would lead to the inclusion of a larger number of studies. Likewise, inclusion of other search bases, such as IndexPsi, Pepsic, and BVS-Psi, together with the consideration of books and book chapters, could broaden the results.

Such considerations, however, do not exclude the hypothesis that, in Latin American countries, as already mentioned in the introduction of this article, the conceptual contribution 
used to study the adversities and processes of community outreach is another. In this case, future studies could focus on the discussion of how the area of Community Psychology has been understood and integrated into - directly or indirectly - the concept of community resilience. However, the need for clarity about the concept of community resilience is reiterated, so as not to be confused with resilience, or other concepts / processes that can be misnamed.

It was verified that the main adversities studied are the disasters of natural or human cause. To a lesser extent, there are studies focusing on the challenges posed by environmental changes and globalization, which results, for example, in the difficulties of growing up in an indigenous community, and the risks generated by poverty and deprivation of resources. Therefore, a vast field of research and intervention, focused on situations of chronic adversity, such as those experienced in the Latin American context (e.g., floods, droughts, violence, poverty, etc.) is open to researchers and professionals interested in community resilience.

With regard to the resources needed to bring about community resilience processes, social capital, infrastructure and cultural ties stand out. These factors result from an integrative analysis, proposed in this article, which sought to establish points of convergence among the pillars of community resilience, traditionally emphasized in Latin American and North American literature. Therefore, it is suggested that future studies should focus on an integrative perspective of community resilience. In addition, it is believed to be important that there is further development of empirical studies on community resilience in the Brazilian context, in addition to the development and evaluation of psychosocial interventions that promote community resilience.

\section{References}

Agani, F., Landau, J., \& Agani, N. (2010). Community-building before, during, and after times of trauma: The application of the linc model of community resilience in kosovo. American Journal of Orthopsychiatry, 80(1), 143-149. doi: http:// doi.org/10.1111/j.1939-0025.2010.01017.x
Aldrich, D., \& Meyer, M. (2015). Social Capital and Community Resilience. American Behavioral Scientist, 59(2), 254-269. doi: http://doi. org/10.1177/0002764214550299

Allmark, P., Bhanbhro, S., \& Chrisp, T. (2014). An argument against the focus on community resilience in public health. BMC Public Health, 14, 62. doi: http://doi.org/10.1186/1471-2458$14-62$

Azkarraga, J., Sloan, T., Belloy, P., \& Loyola, A. (2012). Eco-localismo y resiliencia comunitaria frente a la crisis civilizatoria. Polis, 33, 19. Retrieved from http://journals.openedition.org/ polis $/ 8400$

Bardin, L. (1977). Análise de conteúdo (L. A. Reto \& A. Pinheiro, Trans.). Lisboa: Edições 70.

Boon, H. J., Cottrell, A., King, D., Stevenson, R. B., \& Millar, J. (2012). Bronfenbrenner's bioecological theory for modelling community resilience to natural disasters. Natural Hazar$d s$, 60(2), 381-408. doi: http://doi.org/10.1007/ s11069-011-0021-4

Coimbra, R., \& Morais, N. (2015). A resiliência em questão: Perspectivas teóricas, pesquisa e intervenção. Porto Alegre, RS: Artmed.

Colten, C. E., Hay, J., \& Giancarlo, A. (2012). Community resilience and oil spills in coastal Louisiana. Ecology and Society, 17(3). doi: http://doi.org/10.5751/ES-05047-170305

Góis, C. W. de L. (2008). Saúde comunitária: Pensar e fazer. São Paulo, SP: Aderaldo \& Rothschild.

Gómez-Baggethun, E., Reyes-García, V., Olsson, P., \& Montes, C. (2012). Traditional ecological knowledge and community resilience to environmental extremes: A case study in Doñana, SW Spain. Global Environmental Change, 22(3), 640-650. doi: http://doi.org/10.1016/j. gloenvcha.2012.02.005

González, A. L. M., \& Gaudino, E. F. G. (2013, August). De la resiliencia comunitaria a la ciudadanía ambiental. Revista Integra Educativa, 6(3), 13-28. Retrieved from http:// www.scielo.org.bo/scielo.php?script=sci_arttex t\&pid=S1997-40432013000300002

González-Muzzio, C. (2013). El rol del lugar y el capital social en la resiliencia comunitaria posdesastre. Aproximaciones mediante un estudio de caso después del terremoto del 27/F. Eure, 39(117), 25-48. doi: http://doi.org/10.4067/ S0250-71612013000200002 
Harte, E. W., Childs, I. R. W., \& Hastings, P. A. (2009). Imizamo Yethu: A case study of community resilience to fire hazard in an informal settlement Cape Town, South Africa. Geographical Research, 47(2), 142-154. doi: http://doi. org/10.1111/j.1745-5871.2008.00561.x

Juliano, M. C., \& Yunes, M. A. (2014). Reflexões sobre rede de apoio social como mecanismo de proteção e promoção de resiliência. Ambiente \& Sociedade, 17(3), 135-154.

Kirmayer, L. J., Sehdev, M., Whitley, R., Dandeneau, S. F., \& Isaac, C. (2009). Community Resilience: Models, Metaphors and Measures. International Journal of Indigenous Health, 5(1), 62-117. doi: http://doi.org/10.1073/pnas.0803780105

Mendes, K. D. S., Silveira, R. C. D. C. P., \& Galvão, C. M. (2008). Revisão integrativa: Método de pesquisa para a incorporação de evidências na saúde e na enfermagem. Texto \& Contexto - Enfermagem, 17(4), 758-764. doi: http://doi. org/10.1590/S0104-07072008000400018

Montero, M. (1984). La psicología comunitaria: orígenes, principios y fundamentos teoricos. Revista Latinoamericana de Psicología, 16(3), $387-$ 400 .

Morais, N. A., \& Koller, S. H. (2011). Abordagem Ecológica do Desenvolvimento Humano, Psicologia Positiva e Ciência: Ênfase na Saúde. In Ecologia do desenvolvimento humano: Pesquisa e intervenção no Brasil. São Paulo, SP: Casa do Psicólogo.

Morais, N., Figueiredo, D., Rodrigues, T., \& Santos, R. (2015). "Mandacaru quando fulora na seca": Um estudo sobre processos de resiliência vividos por moradores do sertão cearense. In R. Coimbra \& N. Morais (Eds.), A resiliência em questão: Perspectivas teóricas, pesquisa e intervenção. Porto Alegre, RS: Artmed.

Norris, F. H., Stevens, S. P., Pfefferbaum, B., Wyche, K. F., \& Pfefferbaum, R. L. (2008). Community resilience as a metaphor, theory, set of capacities, and strategy for disaster readiness. American Journal of Community Psychology, 41(1-2), 127-150. doi: http://doi.org/10.1007/s10464007-9156-6

Nuwayhid, I., Zurayk, H., Yamout, R., \& Cortas, C. S. (2011, March). Summer 2006 war on Lebanon: A lesson in community resilience. Global Public Health, 6, 505-519. doi: http://doi.org/10 $.1080 / 17441692.2011 .557666$
Nystad, K., Spein, A. R., \& Ingstad, B. (2014). Community resilience factors among indigenous Sámi adolescents: A qualitative study in Northern Norway. Transcultural Psychiatry, 51(5), 651-672. doi: http://doi.org/10.1177/1363461514532511

Ojeda, E. (2005). Uma concepção latino-americana: A resiliência comunitária. In A. Melillo \& E. Ojeda (Eds.), Resiliência: Descobrindo as próprias fortalezas (pp. 47-57). Porto Alegre, RS: Artmed.

Ojeda, E., La Jara, A., \& Márquez, C. (2007). Resiliência Comunitária. In L. Hoch \& S. Rocca (Eds.), Sofrimento, resiliência e fé: Implicações para as relações de cuidado (pp. 33-56). São Leopoldo, RS: Sinodal.

Pfefferbaum, R. L., \& Pfefferbaum, B. (2013). Community resilience to disasters for mental health professionals. Direcitions in Psychiatry, 33(2), 135-145.

Plough, A., Fielding, J. E., Chandra, A., Williams, M., Eisenman, D., Wells, K. B., ...Magaña, A. (2013). Building Community Disaster Resilience: Perspectives from a Large Urban County Department of Public Health. American Journal of Public Health, 103(7), 1190-1197. doi: http:// doi.org/10.2105/AJPH.2013.301268

Poletto, M., \& Koller, S. H. (2008). Contextos ecológicos: Promotores de resiliência, fatores de risco e de proteção. Estudos de Psicologia (Campinas), 25(3), 405-416. doi: http://doi.org/10.1590/ S0103-166X2008000300009

Poortinga, W. (2012). Community resilience and health: The role of bonding, bridging, and linking aspects of social capital. Health and Place, 18(2), 286-295. doi: http://doi.org/10.1016/j. healthplace.2011.09.017

Quintal, M. de F. (2016). Desafios atuais e antigas sutilezas nas práticas da psicologia social comunitária. Psicología, Conocimiento Y Sociedad, 6(1), 131-163.

Rob, A. (2012). Building Community Resilience. Proceedings of the Institution of Civil Engineers, 165(CE6), 59-64.

Rutter, M. (1993). Resilience : Some Conceptual Considerations. Journal of Adolecent Health, 14(8), 626-631.

Smith, J. W., Moore, R. L., Anderson, D. H., \& Siderelis, C. (2012). Community Resilience in Southern Appalachia: A Theoretical Framework 
and Three Case Studies. Human Ecology, 40(3), 341-353. doi: http://doi.org/10.1007/s10745012-9470-y

Ungar, M. (2011). Community resilience for youth and families: Facilitative physical and social capital in contexts of adversity. Children and Youth Services Review, 33(9), 1742-1748. doi: http://doi.org/10.1016/j.childyouth.2011.04.027

Wexler, L., Joule, L., Garoutte, J., Mazziotti, J., \& Hopper, K. (2013). "Being responsible, respectful, trying to keep the tradition alive:" Cultural resilience and growing up in an Alaska Native community. Transcultural Psychiatry, 51(5), 693-712. doi: http://doi. org/10.1177/1363461513495085

White, R. K., Edwards, W. C., Farrar, A., \& Plodinec, M. J. (2014). A Practical Approach to Building Resilience in America's Communities. American Behavioral Scientist, 59(2), 200-219. doi: http://doi.org/10.1177/0002764214550296

Wilson, G. A. (2012). Community resilience, globalization, and transitional pathways of decision-making. Geoforum, 43(6), 1218-1231. doi: http://doi.org/10.1016/j.geoforum.2012.03.008
Wilson, G. A. (2013a). Community resilience, policy corridors and the policy challenge. Land Use Policy, 31, 298-310. doi: http://doi. org/10.1016/j.landusepol.2012.07.011

Wilson, G. A. (2013b). Community resilience, social memory and the post-2010 Christchurch (New Zealand) earthquakes. Area, 45(2), 207-215. doi: http://doi.org/10.1111/area.12012

Zappe, J., Yunes, M. A., \& Dell'aglio, D. (2015). Psicologia dos desastres e resiliência comunitária: Reflexões sobre o incêndio da boate Kiss em Santa Maria/RS. In R. M. Coimbra \& N. A. Morais (Eds.), A resiliência em questão: Perspectivas teóricas, pesquisa e intervenção. Porto Alegre, RS: Artmed.

Recceived: 23/05/2016

$1^{\text {st }}$ revision: 07/05/2017

Accepted: 02/09/2017

(cc) BY 1 (C) The Author(s), 2018. Open Access. This article is distributed under the terms of the Creative Commons Attribution 4.0 International License (http://creativecommons.org/licenses/by/4.0/), which permits unrestricted use, distribution, and reproduction in any medium, provided you give appropriate credit to the original author(s) and the source, provide a link to the Creative Commons license, and indicate if changes were made. 